\title{
EFFECT OF SILICON NUTRIENT AND SALINITY (ABIOTIC STRESS) ON TOMATO PLANT (Solanum lycopersicum)
}

\author{
NURAAINA ATIQAH AB GHANI, ASAMOAH FREDERICK OSEI, CHONG SOK LENG AND \\ SITI NORDAHLIAWATE MOHAMED SIDIQUE*
}

Laboratory Laboratory for Pest, Disease and Microbial Biotechnology (LAPDiM), Faculty of Fisheries and Food Science, Universiti Malaysia Terengganu (UMT), 21030 Kuala Nerus, Terengganu, Malaysia.

*Corresponding author: dahliasidique@umt.edu.my

http://doi.org/10.46754/umtjur.2021.10.005

\begin{abstract}
Tomato (Solanum lycopersicum) imports have increased in Malaysia due to high demand. One of the constraints to local production is excessive salinity in soils that leads to toxicity in crops, reduction in soil fertility and reduction of availability of water to tomato plant that is known to be sensitive to high salinity. Nevertheless, silicon nutrient proven could protect plants from abiotic stress. Therefore, the objectives of this study were to determine the plant growth of tomato plant treated with silicon $(\mathrm{Si})$ under salinity stress and to observe the physical changes of stems. A total of ten treatments (T1 - T10) were applied with different concentrations of silicon: $0.5 \% \mathrm{Si}(\mathrm{v} / \mathrm{v}), 1.5 \%$ $\mathrm{Si}(\mathrm{v} / \mathrm{v}), 2.5 \% \mathrm{Si}(\mathrm{v} / \mathrm{v})$, potassium silicate as positive control whereas negative control (only water and $0.5 \% \mathrm{NaCl}$ ) and a mixture of equal volumes of the silicon and potassium silicate treatments with $0.5 \% \mathrm{NaCl}$. The treatments were applied once a week $(40 \mathrm{ml}$ for each plant pot). Throughout this study, plant growth data was collected (plant height, diameter of stems, time of anthesis, number of fruits, and chlorophyll content). Results showed that with $0.5 \% \mathrm{Si}(\mathrm{v} / \mathrm{v})$ and $1.5 \% \mathrm{Si}(\mathrm{v} / \mathrm{v})$ (with $0.5 \% \mathrm{NaCl}$ ), the tomato plants grow well especially in plant height, number of leaves and chlorophyll contents. Furthermore, cross section of stems showed a significant difference $(\mathrm{p}<0.05)$ in stem diameter among treated plants $[2.5 \%$ potassium silicate (T4), $0.5 \% \mathrm{Si}(\mathrm{v} / \mathrm{v})+0.5 \% \mathrm{NaCl}(\mathrm{T} 6)$ and $2.5 \%$ potassium silicate $+0.5 \% \mathrm{NaCl}$ (T9) ] and control $(0.5 \% \mathrm{NaCl})$. However, the largest vascular bundle width was recorded in plants treated with $1.5 \% \mathrm{Si}(\mathrm{v} / \mathrm{v})$. This study has proven that tomato plants could uptake silicon and improve the plant growth under salinity stress conditions and giving potential for Si as biostimulant to other Solanaceae family (potato, pepper and eggplant).
\end{abstract}

Keywords: Tomato, silicon, silicic acid, salinity and abiotic.

\section{Introduction}

Tomato (Solanum lycopersicum) belongs to the family Solanaceae and its genus, Solanum, is the largest genus in the Solanaceae family (Bergougnoux, 2014). Fresh tomatoes are widely used for cooking, canning, juices, pulp and sauces and a very good source of lycopene, $\beta$-carotene and vitamins (A and $\mathrm{C}$ ) (Bergougnoux, 2014; Massaretto et al., 2018).

The production and marketing of tomatoes in Malaysia over the past decade has become a serious concern with a decrease in production and an increase in importation (Islam et al., 2012). One of the key constraints to tomato production is the salinity levels of the growing media. Saline soils generally occur in low rainfall region in Malaysia and the global climate change causing precipitation changes that will impact on soil salinization and agriculture production (Teh \& Koh, 2016). Increasing salinity causes reduction in leaf photosynthesis (Maggio et al., 2007), leaf transpiration and plant water status (Romero-Aranda et al., 2001; Maggio et al., 2004) which give an impact on tomato plant yield.

Researchers have reported on the importance of silicon application to crop production (Miyake \& Takahashi, 1986; Ma et al., 2004; Datnoff et al., 2007; Epstein, 2009; Adrees et al., 2015). Although it is not considered an essential plant element, the effect of silicon application ameliorating metal toxicities (Hammond et al., 1995; Iwasaki et al., 2002) and overcoming salinity stress in plants has been intensively studied (Ma, 
2004; Liang et al., 2007; Zhu \& Gong, 2014). Silicon has been reported to reduce salt stress in wheat (Ahmad et al., 1992), barley (Liang et al., 1998), mesquite (Prosopis juliflora) (Bradbury \& Ahmad 1990), spinach and tomato (Gunes et al., 2007; Hoffmann et al., 2020). Si application could reduce water loss from plants and increase the plant water status in salinity stress conditions (Avestan et al., 2019).

Moreover, polymerization of silicic acid within the apoplast, leads to the formation of an amorphous silica barrier (biosilicification) (Exley, 2015), which can help alleviate abiotic stresses from potential toxicants such as aluminum (Al), manganese (Mn), cadmium $(\mathrm{Cd})$, zinc $(\mathrm{Zn})$, and sodium $(\mathrm{Na})$, into the symplast and/or transpiration stream (Rogalla \& Römheld, 2002; Wang et al., 2004; Fauteux et al., 2005; Saqib et al., 2008; Ma et al., 2015; Guerriero et al., 2016). In addition, Si also increased cell-wall binding of $\mathrm{Na}+$ in the root whereas its transport to the shoot proven decreased (Ahmad et al., 1992; Saqib et al., 2008). This study was therefore designed to observe the effect of silicon nutrient in tomato plant growth that is classified as sensitive to high salinity.

\section{Materials and Methods}

\section{Planting Material and Experimental Plot Design}

Seeds of the tomato hybrid Super Star (Green World Genetics Sdn. Bhd.) was chosen and seed viability was tested. The study was in two phases: the first phase was a seed germination study (20 days) and the second phase was the 100 days field assessment (plant growth). The tomato plants were grown inside a polybag with a standard growth media ratio 3:2:1 (top soil: sand: compost) and arranged in a completely randomised design block (CRBD).

\section{Treatments and Treatment Preparation}

The silicon nutrient Sika (72\% silicic acid) was obtained from Siben Ltd. (Taiwan) whereas the potassium silicate and sodium chloride were both from R\&M chemicals (UK). The treatments were prepared with distilled water and applied as scheduled (Table 1).

Table 1: Ten treatments were applied in this study by applying silicon ( $\mathrm{Si}$ ), potassium silicate (positive control) and negative control ( $\mathrm{NaCl}$ and only water) in the second phase of plant growth (100 days)

\begin{tabular}{cc}
\hline *Treatment & Detail \\
\hline T1 & $0.5 \%$ silicon $(\mathrm{v} / \mathrm{v})$ \\
T2 & $1.5 \%$ silicon $(\mathrm{v} / \mathrm{v})$ \\
T3 & $2.5 \%$ silicon $(\mathrm{v} / \mathrm{v})$ \\
T4 & $2.5 \%$ Potassium silicate (positive control) \\
T5 & Only water (negative control) \\
T6 & $0.5 \%$ silicon $(\mathrm{v} / \mathrm{v})+0.5 \% \mathrm{NaCl}$ \\
T7 & $1.5 \%$ silicon $(\mathrm{v} / \mathrm{v})+0.5 \% \mathrm{NaCl}$ \\
T8 & $2.5 \%$ silicon $(\mathrm{v} / \mathrm{v})+0.5 \% \mathrm{NaCl}$ \\
T9 & $2.5 \% \mathrm{Potassium} \mathrm{silicate}+0.5 \% \mathrm{NaCl}$ \\
T10 & $0.5 \% \mathrm{NaCl} \mathrm{(negative} \mathrm{control)}$
\end{tabular}

*40 ml per plant pot

\section{Germination Test}

In the germination study, $1.5 \mathrm{~mL}, 2.5 \mathrm{~mL}$ and $5 \mathrm{~mL}$ of the $0.5 \% \mathrm{Si}(\mathrm{v} / \mathrm{v})$ treatments were given to each 10 seedlings (four replicates) grown inside peat moss media. The number of seeds germinating per treatment replication was counted and recorded whereas seedlings were observed and, data was collected every four days for 20 days. 


\section{Field Assessments}

Data was collected on plant growth parameters such as plant height, diameter of stem, and leaf chlorophyll content. Data on anthesis, fruiting and the cross section of stem (vascular bundle) was assessed as well.

\section{Plant Height and Stem Diameter}

The plant height and stem diameter were measured with a measuring tape on the $100^{\text {th }}$ day after transplanting. Plant height was measured from the media surface to the top of the plant canopy while stem diameter was measured 10 $\mathrm{cm}$ above the growing media surface.

\section{Leaf Chlorophyll Content}

Measurement of leaf chlorophyll content was determined by using SPAD-502 chlorophyll metre (Konica Minolta, Japan). The SPAD 502 meter is an alternative method for the measurement of relative leaf chlorophyll levels since the conventional method is destructive. The SPAD values were recorded once every two weeks.

\section{Anthesis and Fruiting}

The number of flowers appearing and setting fruits were counted and recorded for each treatment replication. Fruit set was then calculated; TFs/TFr x 100 where TFs: the total number of fruits setting per plant and TFr: the total number of flowers appearing on the same plant (Alburquerque et al., 2004).

\section{Physical Changes of Stems}

A cross-section of the stems of the tomato plants from each treatment was made and observed under the microscope. The sections were transferred gently into a petri dish and a drop of toluidine blue stain was added. After five minutes, stain was removed by blotting with filter paper. Distilled water was added into the petri dish for cleaning the stains and this was repeated until the excess stain was washed out. The sections were then transferred gently onto a microscopic slide and a filter paper was used to blot out the excess water. Two drops of mountant were added (glycerol:water, 1:1) and then covered with a coverslip. The sections were observed at $4 \mathrm{x}$ magnification under a compound microscope and photos were taken. The thickness of the vascular bundle of the sections was then measured.

\section{Statistical Analysis}

Data was computed and graphs were generated with Microsoft Excel files. ANOVA was carried out with SPSS version 20.0 and values were compared with Tukey's HSD. Differences were considered significant when the $\mathrm{P}$ value was less than 0.05 .

\section{Results and Discussion}

\section{Germination Test}

Results from the germination test showed that each treatment had different effects on the rate of germination of the tomato seeds. The application of $2.5 \mathrm{ml}$ showed the greatest performances in seed germination except T1 (Figure 1). Nevertheless, T1 was the greatest in seed germination compared to others when amount of $\mathrm{Si}$ was $1.5 \mathrm{ml}$ (Figure 1). There was a significant difference $(\mathrm{P}<0.05)$ of $1.5 \mathrm{ml} \mathrm{Si}$ treated plants with plants given abiotic stress ( $110-0.5 \% \mathrm{NaCl}$ ) (Figure 1). Results also showed that seedling growth was better for 1.5 $\mathrm{ml}$ of $\mathrm{Si}$ and $2.5 \mathrm{ml}$ compared to the highest volume being applied, $5 \mathrm{ml}$ (Figure 1) for both Si treated plants and mixed with $\mathrm{NaCl}$. Only 2.5 $\mathrm{ml}$ potassium silicate with an add on $0.5 \% \mathrm{NaCl}$ seedlings were well germinated (Figure 1).

The toxic effects of sodium on seeds will prevent germination, and high salinity had been proven to reduce enzymatic actions that are favourable for seed germination (Romero et al., 2001). Thus, the improvement in the germination values recorded in the silicon treated seeds can therefore be attributed to $\mathrm{Si}$ ions having the ability to prevent the $\mathrm{Na}$ ions 
absorption (Hashemi et al., 2010). Furthermore, Ca and Mg due to a salt dilution effect that will under salt stress, Si had caused increase of K, improve seedlings growth (Li et al., 2015).

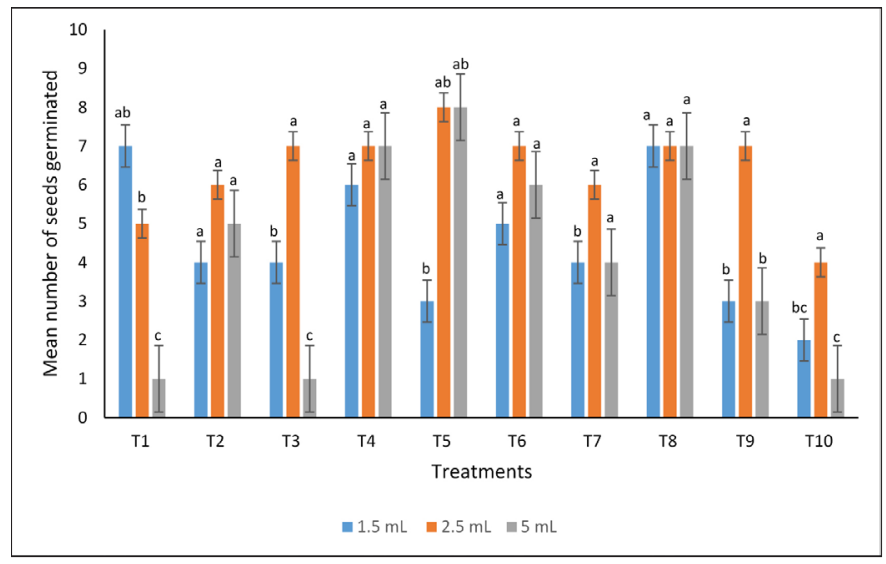

Figure 1: Mean number of seeds germinated after being treated with different amounts of $0.5 \% \mathrm{Si}(\mathrm{v} / \mathrm{v})$ and $0.5 \% \mathrm{NaCl}$ (salinity stress) for 20 days (treatments were given at a four-day interval)

\section{Plant Height and Stem Diameter}

Differences in plant height were observed between the treatments with some plants showing a faster growth rate on day 60 after transplanting (Figure 2). Results showed that there was a significant difference $(P<0.05)$ of the plant height $\mathrm{T} 10(0.5 \% \mathrm{NaCl})$ with other treatments T1, T2 and T6 $[0.5 \%$ silicon $(\mathrm{v} / \mathrm{v})$; $1.5 \%$ silicon $(\mathrm{v} / \mathrm{v})$ and $0.5 \%$ silicon $(\mathrm{v} / \mathrm{v})+$ $0.5 \% \mathrm{NaCl}$, respectively] (Fig. 3). There is a possible indication that Si could improve saline condition, especially $\mathrm{T} 6$ with additional $0.5 \%$ silicon $(\mathrm{v} / \mathrm{v})$ tomato plants were growing well (Figure 3). Also, T6 stem diameter $(7.48 \mathrm{~cm})$ was significantly different $(P<0.05)$ with T10 $(5.08$ $\mathrm{cm})$ (Figure 4). The others great stem diameter were significantly different $(P<0.05)$ with T10 e.g., T4 (2.5\% potassium silicate) and T9 $(0.25 \%$ potassium silicate $+0.5 \% \mathrm{NaCl}), 7.80$ $\mathrm{cm}$ and $7.38 \mathrm{~cm}$, respectively (Figure 4).

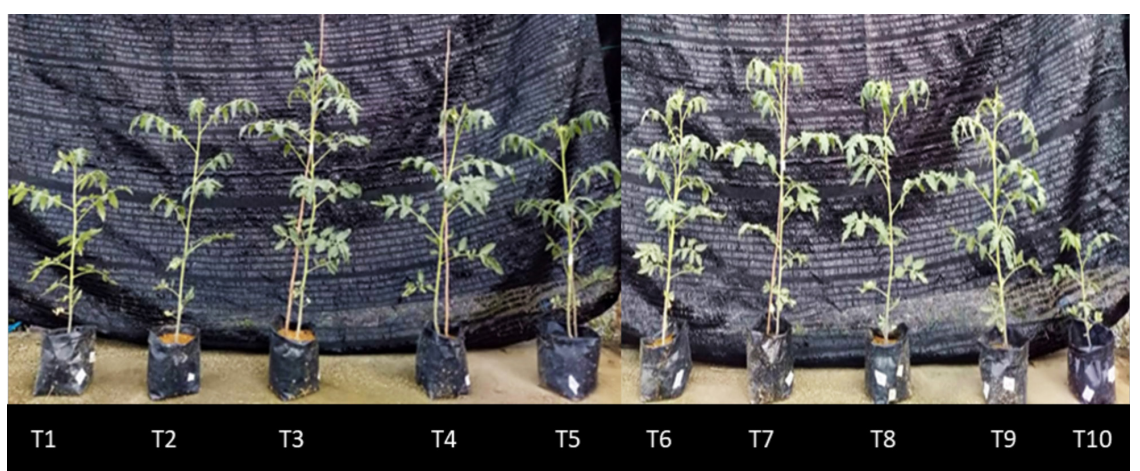

Figure 2: Plant height of tomato plants was observed on day 60 after transplanting and treated with silicon and potassium silicate (Table 1). Only plants given silicon were growing well (T6, T7, T8 and T9) under abiotic stress compared to control $\mathrm{T} 10(0.5 \% \mathrm{NaCl})$ 
Saberi et al. (2011) had reported that both tomato and forage sorghums stem diameter was one of the growth parameters which decreased with increasing salinity. However, Epstein (1999) indicated that the favourable effects of $\mathrm{Si}$ on crop plants seem to originate from reinforcement of the cell walls due to deposition of $\mathrm{Si}$ in form of amorphous silica $\left(\mathrm{SiO}_{2} \cdot \mathrm{nH}_{2} \mathrm{O}\right)$ and opal phytoliths which increases the plant growth. Thus, increases in catalase activity of the whole plant and cell wall under stress conditions may likely be the cause of growth in plant height and stem diameter after silicon treatments had been reported in tomato and barley (Liang et al., 2003; Al-aghabary et al., 2005). Lee et al. (2010) found that the application of silicon to plants increases endogenous gibberellins and reduces the levels of $\mathrm{ABA}$ and proline in plants under stress that improve plant growth. In addition, potassium is recognized as an essential macronutrient for optimal plant growth by promoting cell growth and contributed to development of plants (White \& Karley, 2010; Oosterhuis et al., 2014).

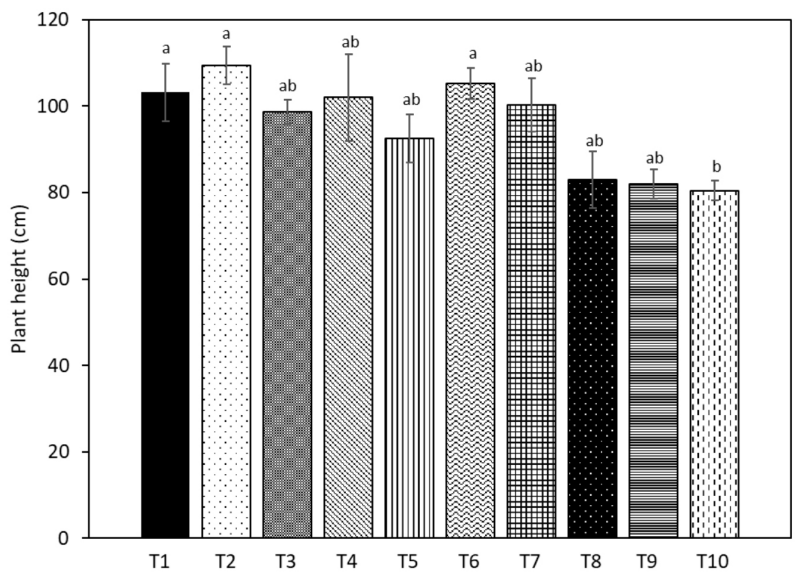

Figure 3: Mean of tomato plant height $(\mathrm{cm})$ after plants were given silicon, potassium silicate and $\mathrm{NaCl}$ (Table 1) for 100 days ( $40 \mathrm{ml}$ per plant pot)

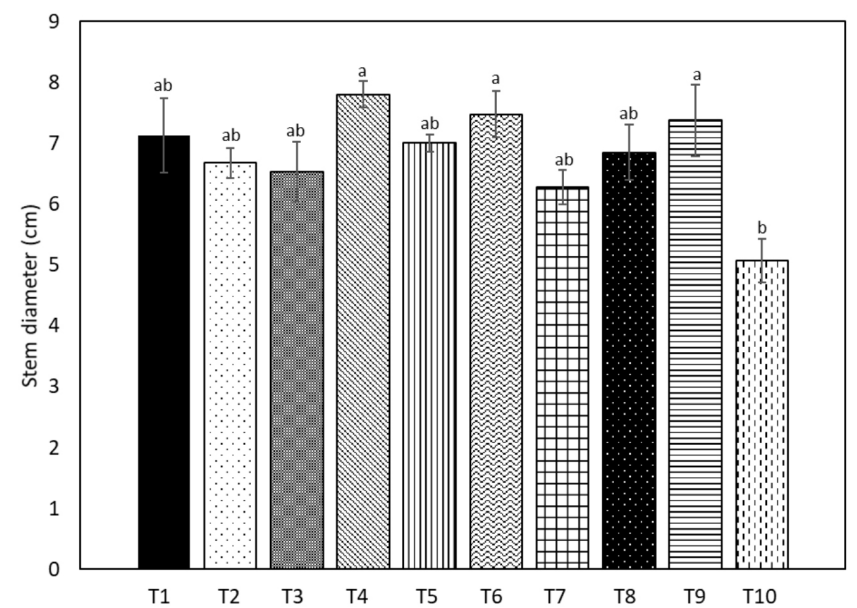

Figure 4: Mean of tomato stem diameter after plants were given silicon, potassium silicate and $\mathrm{NaCl}$ (Table 1) for 100 days ( $40 \mathrm{ml}$ per plant pot) 


\section{Leaf Chlorophyll Content (SPAD Units)}

There were significant differences $(p<0.05)$ in chlorophyll content between some of the treatments from week four until week 14 (Table 2). In week four, $\mathrm{T} 1$ treated plants $[0.5 \% \mathrm{Si}$ $(\mathrm{v} / \mathrm{v})]$ recorded the highest chlorophyll content then in week 8 , T6 $[(0.5 \% \mathrm{Si}(\mathrm{v} / \mathrm{v})+0.5 \%$ $\mathrm{NaCl}]$ followed by $\mathrm{T} 2[(1.5 \% \mathrm{Si}(\mathrm{v} / \mathrm{v})]$ for week
12 and week 14 (Table 2). The result from plants treated with $0.5 \% \mathrm{NaCl}$ (T10) showed the least chlorophyll content in SPAD units in week four until week 14 (Table 2). However, $\mathrm{Si}$ and potassium silicate showed a significant difference $(\mathrm{p}<0.05)(\mathrm{T} 6, \mathrm{~T} 7, \mathrm{~T} 8$ and T9) when applied into tomato plants with abiotic stress conditions (applied $0.5 \% \mathrm{NaCl}$ ) (Table 2).

Table 2: Mean of leaves chlorophyll content (SPAD units) from week four until week 14 of tomato plants growing

\begin{tabular}{lllll}
\hline \multicolumn{1}{c}{ Treatment } & \multicolumn{1}{c}{ Week 4 } & \multicolumn{1}{c}{ Week 8 } & \multicolumn{1}{c}{ Week 12 } & \multicolumn{1}{c}{ Week 14 } \\
\hline T1 [0.5\% silicon (v/v)] & $36.80 \pm 0.83 \mathrm{a}$ & $49.43 \pm 0.93 \mathrm{a}$ & $55.91 \pm 2.24 \mathrm{ab}$ & $59.07 \pm 0.83 \mathrm{ab}$ \\
T2 [1.5\% silicon (v/v)] & $34.94 \pm 1.27 \mathrm{a}$ & $46.9 \pm 0.58 \mathrm{ab}$ & $59.97 \pm 2.88 \mathrm{a}$ & $61.64 \pm 1.54 \mathrm{a}$ \\
T3 [(2.5\% silicon (v/v)] & $35.05 \pm 0.65 \mathrm{a}$ & $47.73 \pm 2.78 \mathrm{a}$ & $49.13 \pm 2.18 \mathrm{ab}$ & $56.55 \pm 2.72 \mathrm{ab}$ \\
T4 (potassium silicate; positive control) & $35.41 \pm 2.31 \mathrm{a}$ & $50.73 \pm 1.63 \mathrm{a}$ & $51.74 \pm 2.23 \mathrm{ab}$ & $57.72 \pm 1.75 \mathrm{ab}$ \\
T5 (only water; negative control) & $33.86 \pm 2.04 \mathrm{ab}$ & $51.49 \pm 2.02 \mathrm{a}$ & $53.79 \pm 2.74 \mathrm{ab}$ & $61.10 \pm 1.98 \mathrm{a}$ \\
T6 [0.5\% silicon (v/v) $+0.5 \% \mathrm{NaCl}]$ & $32.14 \pm 1.4 \mathrm{ab}$ & $49.76 \pm .2 .13 \mathrm{a}$ & $56 \pm 2.70 \mathrm{ab}$ & $58.22 \pm 0.85 \mathrm{ab}$ \\
T7 [1.5\% silicon (v/v) $+0.5 \% \mathrm{NaCl}]$ & $33.44 \pm 0.92 \mathrm{ab}$ & $45.95 \pm 0.91 \mathrm{ab}$ & $54.09 \pm 2.39 \mathrm{ab}$ & $56.03 \pm 1.24 \mathrm{ab}$ \\
T8 [2.5\% silicon (v/v) $+0.5 \% \mathrm{NaCl}]$ & $35.74 \pm 1.75 \mathrm{a}$ & $46.11 \pm 1.8 \mathrm{ab}$ & $54.26 \pm 2.20 \mathrm{ab}$ & $55.04 \pm 0.92 \mathrm{ab}$ \\
T9 (potassium silicate) $+0.5 \% \mathrm{NaCl})$ & $34.34 \pm 2.09 \mathrm{ab}$ & $48.51 \pm 1.6 \mathrm{a}$ & $54.35 \pm 2.60 \mathrm{ab}$ & $61.27 \pm 0.52 \mathrm{a}$ \\
T10 $(0.5 \% \mathrm{NaCl}$; negative control) & $29.96 \pm 2.11 \mathrm{~b}$ & $43.80 \pm 1.77 \mathrm{~b}$ & $50.18 \pm 2.24 \mathrm{~b}$ & $51.35 \pm 0.98 \mathrm{~b}$ \\
\hline
\end{tabular}

Values are means \pm standard error. Values with different letters are statistically significantly different at $\mathrm{p}<0.05$

Silicon application has been proven to influence the absorption of plant macronutrients and micronutrients that enhances the photosynthetic rates of plants (Liang et al., 1996; Adams, 2002; Savvas et al., 2002). The micronutrient Ferum $(\mathrm{Fe})$ is one of the most essential for increasing the concentration of photosynthetic pigments and found to be absorbed well together with Si (Teixeira et al., 2020). In strawberry plant, chlorophyll content, leaf number, leaf area and petiole length were increased significantly when potassium silicate was applied (Dehghanipoodeh et al., 2018).

\section{Anthesis and Fruiting}

Results showed that the highest number of flowers was from the tomato plants treated with $2.5 \%$ potassium silicate (T4) whereas there were no flowers in plants treated with $\mathrm{NaCl}$ (T10) as well as no fruits until at the end of 100 days (Table 3). The greatest percentage of fruit set $(63.6 \%)$ was T9 (potassium silicate +0.5 $\% \mathrm{NaCl}$ ) and followed by T3 (41.6\%) and, T4 (36.8\%) whereas others were below $30 \%$ of fruit set (Table 3 ). In addition, fruits that had been affected with blossom end rot were not properly intact. 
Table 3: The flower and fruit setting of tomato plants days after transplanting until final harvesting (100 days)

\begin{tabular}{lccccc}
\multicolumn{1}{c}{ Treatment } & $\begin{array}{c}\text { Total Flower } \\
\text { (TF) }\end{array}$ & $\begin{array}{c}\text { Intact } \\
\text { Fruit (IF) }\end{array}$ & $\begin{array}{c}\text { Damaged } \\
\text { Fruit (DF) }\end{array}$ & $\begin{array}{c}\text { Total Fruit } \\
\text { (TFr) }\end{array}$ & $\begin{array}{c}\text { Fruit Set } \\
\text { Percentage (\%) }\end{array}$ \\
\hline T1 [0.5\% silicon (v/v)] & 17 & 3 & 2 & 5 & 29.4 \\
T2 [(1.5\% silicon (v/v)] & 15 & 4 & 0 & 4 & 26.6 \\
T3 [(2.5\% silicon (v/v)] & 12 & 3 & 2 & 5 & 41.6 \\
T4 (positive control; & 19 & 4 & 3 & 7 & 36.8 \\
potassium silicate) \\
T5 (negative control; only
\end{tabular}

Previous study of silicon fertilization in the form of potassium and calcium silicates showed that it could increase the tomato yield and reduce the occurrence of cracked fruits (Marodin et al., 2014). Similar results with Si applied directly to soil bed that showed tomato yield could reach up to $15.9 \%$, compared to on average by $12.0 \%$ without Si (Liang et al., 2015).

\section{Stem Tissues}

The thickest vascular bundle was $\mathrm{T} 2[1.5 \% \mathrm{Si}$ $(\mathrm{v} / \mathrm{v})]$ tomato plants and there was a significant difference $(\mathrm{P}<0.05)$ of vascular bundle thickness between $\mathrm{T} 10(0.5 \% \mathrm{NaCl})$ and other treatments (Figure 5a). Microscopic view showed thicker stem epidermis of Si treated plants than control (without Si) (Figure 5b).

Several works have confirmed that Si supported plant cell division, nutrients absorption and plant enzyme activation are causing physical changes in plant parts (Savvas et al., 2002; Liang et al., 2003; Al-aghabary et al., 2004). Rice with problem of Si deficiencies have reduced vascular bundle formation and low lignin levels leading to plant logging (Ma et al., 2002; Inanaga et al., 2002). This study showed potential of silicon and potassium silicate to improve vascular bundle, and consequently reduce the deleterious effect of the saline conditions. 

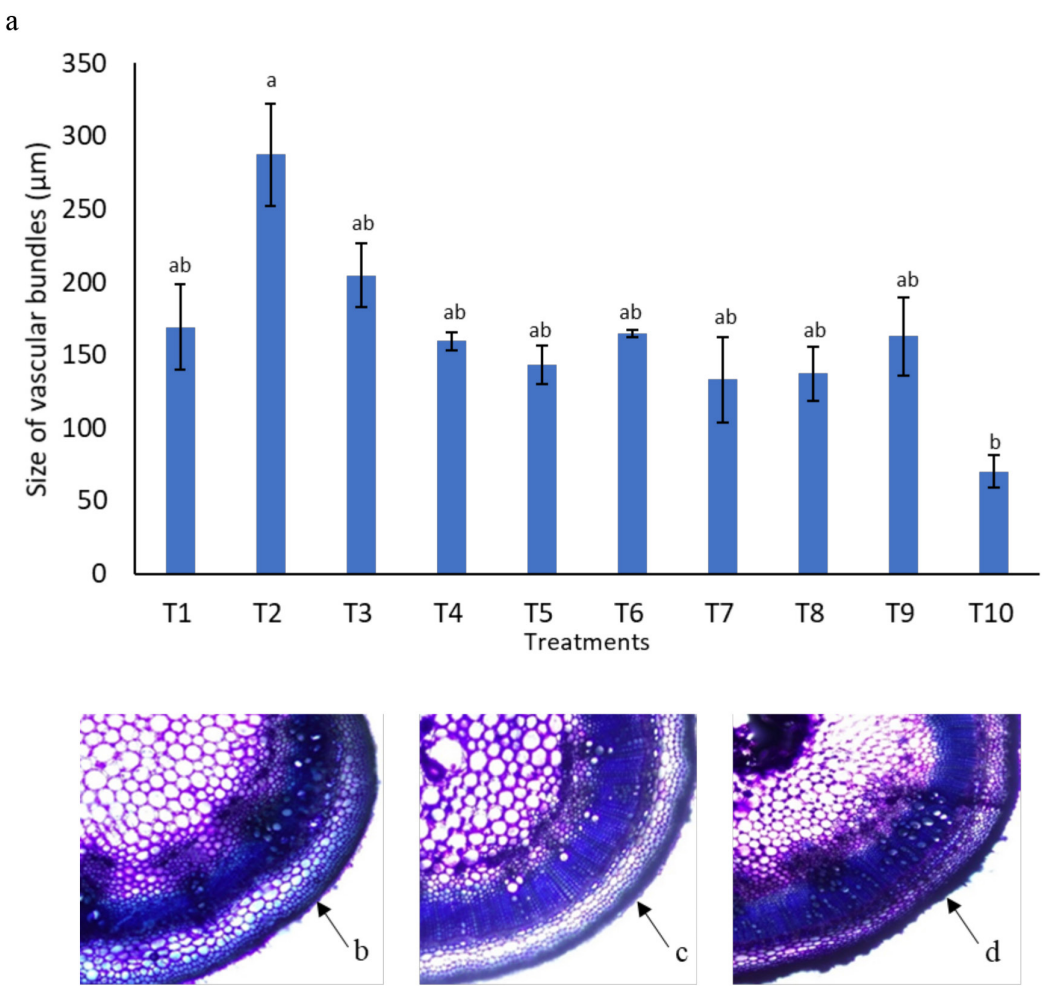

Figure 5: (a) Mean of vascular bundle size and values with different letters are significantly different statistically at $\mathrm{p}<0.05$ (See Table 1 ; treatment $\mathrm{T} 1-\mathrm{T} 10$ ).

The thickness off stem epidermis staining with toluidine blue (arrow) showed differences between control (without silicon, b) and plants with silicon (c and d)

\section{Conclusion}

This study has confirmed that although silicon is not classified as an essential plant nutrient, it is beneficial to improve growth and development of tomato plants especially under abiotic stress conditions. Moreover, the positive effects observed in the Si treated tomato plants indicated they could uptake silicon in silicic acid form despite the low capacity as Si-accumulator plant, by improving vegetative growth. Therefore, supplementing $\mathrm{Si}$ and $\mathrm{P}$ concentrations could aid tomato cultivars under $\mathrm{NaCl}$ stress. Further Si research on other Solanaceae family such as potato, pepper and eggplant will give benefits in controlling biotic and abiotic stress.

\section{Acknowledgements}

We thank staff and postgraduates in Laboratory for Pest, Disease and Microbial Biotechnology (LAPDiM) and crop science laboratory, Faculty of Fisheries and Food Science, UMT for their assistance throughout this study. 


\section{References}

Adams, P. (2002). Nutritional control in hydroponics. In: Savvas, D. and Passam, H. C. (eds), Hydroponic Production of Vegetables and Ornamentals. Athens, Greece, Embryo Publications. p.211-261.

Ahmad, R., Zaheer, S. H., \& Ismail, S. (1992). Role of silicon in salt tolerance of wheat (Triticum aestivum L.). Plant Science, 85, 43-50.

Al-aghabary, K., Zhu, Z., \& Shi, Q. (2005). Influence of silicon supply on chlorophyll content, chlorophyll fluorescence, and antioxidative enzyme activities in tomato plants under salt stress. Journal of Plant Nutrition, 27(12), 2101-2115.

Alburquerque, N., Burgos, L., \& Egea, J. (2004). Influence of flower bud density, flower bud drop and fruit set on apricot productivity. Scientia Horticulturae, 102(4), 397-406.

Avestan, S., Ghasemnezhad, M., Esfahani, M., \& Byrt, C. (2019). Application of NanoSilicon Dioxide Improves Salt Stress Tolerance in Strawberry Plants. Agronomy Journal, 9 (5), 246.

Bélanger, R. R., Bowen, P. A., Ehret, D. L., \& Menzies, J. G. (1995). Soluble silicon: Its role in crop and disease management of greenhouse crops. Plant Disease, 79(4), 329.

Bélanger R. R., Dik A. J., \& Menzies G. J. (1998). Powdery mildews: recent advances toward integrated control. In: Boland G. J. and Kuykendall L. D., (eds), Plant-microbe Interactions and Biological Control. New York, Marcel Dekker. pp. 89-109.

Bergougnoux, V. (2014). The history of tomato: from domestication to biopharming. Biotechnology Advances, 32(1), 170-189.

Bradbury, M., \& Ahmad, R. (1990). The effect of silicon on the growth of Prosopis juliflora growing in saline soil. Plant and Soil, 125(1), 71-74.
Cuartero, J., \& Fernández-Muñoz, R. (1998). Tomato and salinity. Scientia Horticulturae, 78(1-4), 83-125.

Dehghanipoodeh, S., Ghobadi, C., Baninasab, B., Gheysari, M., \& Shiranibidabadi, S. (2018). Effect of silicon on growth and development of strawberry under water deficit conditions. Horticultural Plant Journal, 4(6), 226-232.

Epstein, E. (1999). Silicon. Annual Review of Plant Biology, 50(1), 641-664.

Exley, C. (2015). A possible mechanism of biological silicification in plants. Frontiers in Plant Science, 6:853.

Fauteux, F., Rémus-Borel, W., Menzies, J. G., \& Bélanger, R. R. (2005). Silicon and plant disease resistance against pathogenic fungi. FEMS Microbiology Letters, 249, 1-6.

Guerriero, G., Hausman, J.-F., \& Legay, S. (2016). Silicon and the plant extracellular matrix. Frontiers in Plant Science, 7:463.

Gunes, A., Inal, A., Bagci, E. G., \& Pilbeam, D. J. (2007). Silicon-mediated changes of some physiological and enzymatic parameters symptomatic for oxidative stress in spinach and tomato grown in sodic-B toxic soil. Plant and Soil, 290(1-2), 103-114.

Hashemi, A., Abdolzadeh, A., \& Sadeghipour, H. R. (2010). Beneficial effects of silicon nutrition in alleviating salinity stress in hydroponically grown canola, Brassica napus L., plants. Soil Science \& Plant Nutrition, 56(2), 244-253.

Hammond, K. E., Evans, D. E., \& Hodson, M. J. (1995). Aluminium/silicon interactions in barley (Hordeum vulgare L.) seedlings. Plant and Soil, 173(1), 89-95.

Hertwig, B., Streb, P., \& Feierabend, J. (1992). Light dependence of catalase synthesis and degradation in leaves and the influence of interfering stress conditions. Plant Physiology, 100(3), 1547-1553. 
Hoffmann, J., Berni, R., Hausman, J. F., \& Guerriero, G. (2020). A Review on the Beneficial Role of Silicon against Salinity in Non-Accumulator Crops: Tomato as a Model. Biomolecules, 10, 1284.

Inanaga, S., \& Okasaka, A. (1995). Calcium and silicon binding compounds in cell walls of rice shoots. Soil Science and Plant Nutrition, 41(1), 103-110.

Islam, G. M. N., Arshad, F. M., Radam, A., \& Alias, E. F. (2012). Good agricultural practices (GAP) of tomatoes in Malaysia: Evidences from Cameron Highlands. African Journal of Business Management, 6(27), 7969-7976.

Lee, S. K., Sohn, E. Y., Hamayun, M., Yoon, J. Y., \& Lee, I. J. (2010). Effect of silicon on growth and salinity stress of soybean plant grown under hydroponic system. Agroforestry Systems, 80(3), 333340 .

Li, H. Zhu, Y. Hu, Y. Han, W., \& Gong, H. (2015). Beneficial effects of silicon in alleviating salinity stress of tomato seedlings grown under sand culture. Acta Physiologiae Plantarum, 37, 71.

Liang, Y. (1999). Effects of silicon on enzyme activity and sodium, potassium and calcium concentration in barley under salt stress. Plant and Soil, 209, 217-224.

Liang Y. C. (1998). Effects of Si on leaf ultrastructure, chlorophyll content and photosynthetic activity in barley under salt stress. Pedosphere, 8, 289-296.

Liang, Y., Sun, W., Zhu, Y.-G., \& Christie, P. (2007). Mechanisms of silicon-mediated alleviation of abiotic stresses in higher plants: a review. Environmental Pollution, 147, 422-428.

Liang, Y., Nikolic, M., Bélanger, R., Gong, H., \& Song, A. (2015). Effect of silicon on crop growth, yield and quality. Silicon in Agriculture. Springer, Dordrecht, pp. 209223,
Ma J. F., \& Takahashi E. (2002). Soil, Fertilizer, and Plant Silicon Research in Japan. Elsevier B.V. Amsterdam, p. 274.

Ma, J. F. (2004). Role of silicon in enhancing the resistance of plants to biotic and abiotic stresses. Soil Science and Plant Nutrition, 50(1), 11-18.

Ma, J., Cai, H., He, C., Zhang, W., \& Wang, L. (2015). A hemicellulose-bound form of silicon inhibits cadmium ion uptake in rice (Oryza sativa) cells. New Phytologist, 206, 1063-1074.

Maggio, A., De Pascale, S., Angelino, G., Ruggiero, C., \& Barbieri, G. (2004). Physiological response of tomato to saline irrigation in long-term salinized soils. European Journal of Agronomy, 21, 149159.

Maggio, A., Raimondi, G., Martino, A., \& De Pascale, S. (2007). Salt stress response in tomato beyond the salinity tolerance threshold. Environmental and Experimental Botany, 59(3), 276-282.

Marodin, J. C., Resende, J. T., Morales, R. G., Silva, M. L., Galvão, A. G., \& Zanin, D. S. (2014). Yield of tomato fruits in relation to silicon sources and rates. Horticultura Brasileira, 32(2), 220-224.

Massaretto, I.L., Albaladejo, I., Purgatto, E., Flores, F.B., Plasencia, F., EgeaFernández, J.M., Bolarin, M.C., \& Egea, I. (2018). Recovering tomato landraces to simultaneously improve fruit yield and nutritional quality against salt stress. Frontiers in Plant Science, 9, 1778.

Miyake, Y., \& Takahashi, E. (1986). Effect of silicon on the growth and fruit production of strawberry plants in a solution culture. Soil Science and Plant Nutrition, 32(2), 321326.

Oosterhuis, D., Loka, D., Kawakami, E., \& Pettigrew, W. (2014). The physiology of potassium in crop production. Advances in Agronomy, 126, 203-234. 
Rogalla, H., \& Römheld, V. (2002). Role of leaf apoplast in silicon-mediated manganese tolerance of Cucumis sativus L. Plant, Cell and Environment, 25, 549-555.

Romero-Aranda, M. R., Jurado, O., \& Cuartero, J. (2006). Silicon alleviates the deleterious salt effect on tomato plant growth by improving plant water status. Journal of Plant Physiology, 163(8), 847-855.

Romero-Aranda, R., Soria, T. \& Cuartero, J. (2001). Tomato plant-water uptake and plant-water relationships under saline growth conditions. Plant Science, 160(2), 265-272.

Saberi, A. R., Siti Aishah, H., Halim, R. A., \& Zaharah, A. R. (2011). Morphological responses of forage sorghums to salinity and irrigation frequency. African Journal of Biotechnology, 47: 9647-9656.

Saqib, M., Zoerb, C., \& Schubert, S. (2008). Silicon-mediated improvement in the salt resistance of wheat (Triticum aestivum) results from increased sodium exclusion and resistance to oxidative stress. Functional Plant Biology, 35, 633-639.

Savvas, D. (2002). Nutrient solution recycling. p.299-343. In: Savva, D. and Passam, H. C. (eds). Hydroponic Production of Vegetables and Ornamentals. Athens, Greece, Embryo Publications.
Stamatakis, A., Papadantonakis, N., Savvas, D., Lydakis-Simantiris, N. \& Kefalas, P. (2003, July). Effects of silicon and salinity on fruit yield and quality of tomato grown hydroponically. In International Symposium on Managing Greenhouse Crops in Saline Environment 609 (pp. 141-147).

The S. Y., \& Koh H. L. (2016). Climate change and soil salinization: impact on agriculture, water and food security. International Journal of Agriculture, Forestry and Plantation, 2 (February), 1-9.

Teixeira, G.C.M., de Mello Prado, R., Oliveira, K.S. et al. (2020). Silicon Increases Leaf Chlorophyll Content and Iron Nutritional Efficiency and Reduces Iron Deficiency in Sorghum Plants. Journal of Soil Science and Plant Nutrition, 20, 1311-1320.

Wang, Y. X., Stass, A., \& Horst, W. J. (2004). Apoplastic binding of aluminum is involved in silicon-induced amelioration of aluminum toxicity in maize. Plant Physiology, 136, 3762-3770.

White, P. J., \& Karley, A. J. (2010). Potassium Cell Biology of Metals and Nutrients. Berlin: Springer, 199-224.

Zhu, Y., \& Gong, H. (2014). Beneficial effects of silicon on salt and drought tolerance in plants. Agronomy for Sustainable Development, 34, 455-472. 
